\title{
PHYSICOCHEMICAL INVESTIGATION OF SOME PRIMITIVE WATER SOURCES IN DISTRICT CHAMPAWAT FOR POTABILITY AND PRESERVATION OF HISTORICAL AESTHETICS, UTTARAKHAND, INDIA
}

\author{
Kiran Patni* ${ }^{*}$ Ashutosh Pratap Pande ${ }^{* *}$, Chitra Pande ${ }^{* * *}$ \\ * Graphic Era Hill University, Department of Allied Sciences, Bhimtal, India \\ ** Laxman Singh Mehar Government Post Graduate College, Department of Chemistry, Pithoragarh, India \\ ${ }^{* * *}$ Dev Singh Bisht Campus, Department of Chemistry, Nainital, India
}

corresponding author: Kiran Patni, e-mail: 93kiranpatni@ gmail.com

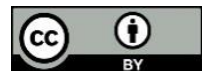

This work is licensed under a

Creative Commons Attribution 4.0

International License

Original scientific paper

Received: August $7^{\text {th }}, 2020$

Accepted: September $21^{\text {st }}, 2020$

HAE-1996

https://doi.org/10.33765/thate.12.1.1

\begin{abstract}
The present study deals with the assessment of physicochemical properties of spring water samples collected from the surroundings of Champawat city, Uttarakhand, India. The total of twenty-three parameters were analysed for the study including $\mathrm{pH}$, total dissolved solids (TDS) (mg/L), electrical conductance $(\mathrm{EC})(\mu \mathrm{S} / \mathrm{cm})$, temperature $(\mathrm{T})\left({ }^{\circ} \mathrm{C}\right)$, dissolved oxygen $(\mathrm{DO})(\mathrm{mg} / \mathrm{L})$, chloride $\left(\mathrm{Cl}^{-}\right)$ $(\mathrm{mg} / \mathrm{L})$, and uranium $(\mathrm{U})(\mu \mathrm{g} / \mathrm{L})$. The seasonal variation was also observed in these samples. In the hills, spring water has been the common source of public water supply from ancient times, therefore this study includes the springs that have survived from the distant past and were being used for drinking purpose at earlier time. However, with time, the quality of these water sources has depleted due to both natural and anthropogenic reasons to such an extent that two of these sources are not in use any more. The analysis has shown that $\mathrm{pH}$ of these samples ranged from $6.74-7.77$, the highest values of TDS and nitrate $\left(\mathrm{NO}_{3}{ }^{-}\right)$were observed to be $500 \mathrm{mg} / \mathrm{L}$ and $39.1 \mathrm{mg} / \mathrm{L}$ respectively. This study can help determine the present state of these ancient water sources, which can be used as alternative water sources in the time of water supply crisis, and maintaining these historical water sources can be an example of sustainable development and preservation of historical aesthetics.
\end{abstract}

Keywords: spring water, physicochemical properties, subterranean spring, drinking water

\section{INTRODUCTION}

Water has always been a life sustaining liquid to humans and all the organisms. In the present time, due to rapid growth in population and industrialization and advanced techniques available for the disposal of water, the quality of water has deteriorated. Anthropogenic activities have proved to be the biggest reason for the contamination of water [1 - 3]. Water is the basic need of all and essential for sustaining basic human functions, health and 
food production. Along with this, it helps in various activities, like digestion of food, adsorption, transportation and removal of toxins and wastes from the body [4]. Humans cannot produce this inevitable element of life and as the life relies on water, the quality of water becomes one of the very essential aspects in order to make it pollution free so that various water sources (ground water, surface water) can be protected. In the context of India, improper disposal of wastewater has become one of the major sources for the water pollution, resulting in various fatal diseases. According to a report of World Health Organization (WHO), $80 \%$ of water contamination results from domestic wastes [5]. Assessment of water quality parameters is very essential in order to authenticate the quality of water regarding potability, e.g., TDS gives the information regarding the presence of inorganic salts and small amounts of organic matter; $\mathrm{pH}$ gives the information regarding the surrounding agricultural land, its aquatic eco system, industrial discharge etc. [6].

Uranium is an omnipresent radionuclide, widely available in the earth's crust [7]. Uranium is toxic both radiologically and chemically. The level of toxicity depends upon the concentration, exposure route, chemical nature, exposure period, solubility of uranium compounds, contact time and route of elimination from the body [8]. Permissible limit of $U$ in drinking water according to the guidelines of India's Atomic Energy Regulatory Board, Department of Atomic Energy is $60 \mu \mathrm{g} / \mathrm{L}$ [9].

The present study deals with the physicochemical assessment of the natural untreated water sources, which have been sustained in Champawat district, Uttarakhand, for a long time. There is no historical evidence that suggests who constructed the Baleshwar temple and the subterranean spring near it, but it is believed that it was built by the rulers of the Chand dynasty in the period between the $10^{\text {th }}$ and the $12^{\text {th }}$ century AD. Other historic aesthetics mentioned here are also assumed to have been built at about the same time. Keeping in view all the health effects caused by different pollutants in water and toxicity due to uranium, this paper aims to evaluate the physicochemical properties as well as the uranium concentration on these historical aesthetics in order to verify the potability of these water sources. These ancient sources, which are still running, can be used as an alternative source of drinking water at the present as well as in the future. However, this can be possible only if the quality of these sources is maintained and analysed in regular time intervals.

\section{MATERIALS AND METHODS}

\section{Study Area}

The present study area covers five locations in the surroundings of the city. All the collected samples were in the form of subterranean springs. Sampling locations with their corresponding GPS coordinates are shown in Table 1 and the map corresponding to sampling locations is shown in Figure 1.

\section{Methods}

The samples were collected from the surroundings of the Champawat city. Washed polypropylene double-capped $250 \mathrm{~mL}$ sampling bottles were used for the collection. The collected samples were tested for a total of 21 parameters, including colour, odour, taste, turbidity, depth, pH, TDS, EC, uranium, DO, temperature etc. The samples were collected before and after the monsoon. The following methods were applied for the analysis:

- Water \& Soil analysis Kit, ITS- 701 was used for the analysis of $\mathrm{pH}, \mathrm{TDS}, \mathrm{EC}$, DO and temperature,

- Mohr's method was used for the analysis of chloride $\left(\mathrm{Cl}^{-}\right)$concentration,

- Hardness was evaluated by complexometric titration using Eriochrome Black-T (EBT) as indicator and Ethylenediaminetetraacetic Acid (EDTA) as titrant, 
Table 1. Location details with their corresponding GPS coordinates

\begin{tabular}{|c|c|c|c|c|c|c|c|c|}
\hline \multirow{2}{*}{ State } & \multirow{2}{*}{ District } & \multirow{2}{*}{ Tehsil } & \multirow{2}{*}{$\begin{array}{c}\text { Sample } \\
\text { No. }\end{array}$} & \multirow{2}{*}{$\begin{array}{c}\text { Location } \\
\text { details }\end{array}$} & \multicolumn{2}{|c|}{ GPS coordinates } & \multirow{2}{*}{$\begin{array}{c}\text { Depth, } \\
\text { m }\end{array}$} & \multirow{2}{*}{$\begin{array}{l}\text { Source of } \\
\text { water }\end{array}$} \\
\hline & & & & & Latitude & Longitude & & \\
\hline \multirow{5}{*}{ Uttarakhand } & \multirow{5}{*}{ Champawat } & \multirow{5}{*}{ Champawa } & 1 & $\begin{array}{l}\text { Selakhola } \\
\text { (Nagnath } \\
\text { temple) }\end{array}$ & 29.33645 & 80.08645 & 1 & \multirow{5}{*}{$\begin{array}{l}\text { Subterranean } \\
\text { springs }\end{array}$} \\
\hline & & & 2 & $\begin{array}{c}\text { Jhijhad } \\
\text { (Rani ka } \\
\text { naula) }\end{array}$ & 29.33386 & 80.08646 & 1.52 & \\
\hline & & & 3 & $\begin{array}{c}\text { Khark } \\
\text { Karki }\end{array}$ & 29.32851 & 80.09092 & 0.91 & \\
\hline & & & 4 & $\begin{array}{c}\text { Baleshwar } \\
\text { temple }\end{array}$ & 29.33631 & 80.09039 & 2.38 & \\
\hline & & & 5 & $\begin{array}{c}\text { Goljyu } \\
\text { temple } \\
\text { (Goljyu ka } \\
\text { naula) }\end{array}$ & 29.33468 & 80.09661 & 1.22 & \\
\hline
\end{tabular}

\section{Location sites in Champawat Town}

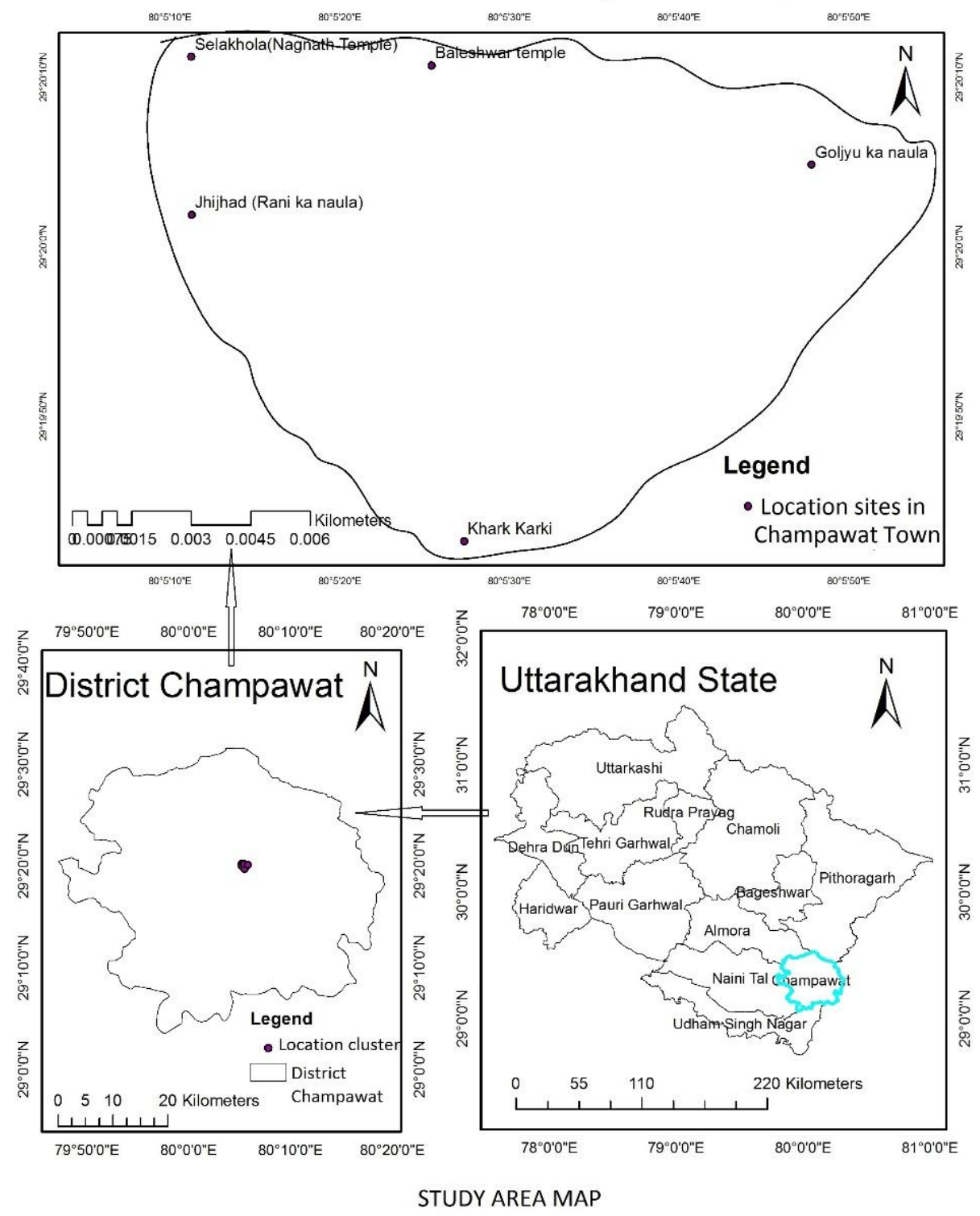

Figure 1. Map representing the sampling locations 
- Multiparameter photometer (HI-83300) by Hanna was used for the analysis of fluoride $\left(\mathrm{F}^{-}\right)$concentration (using SPADNS method), nitrate $\left(\mathrm{NO}_{3}^{-}\right)$ concentration (using cadmium reduction method), sulphate $\left(\mathrm{SO}_{4}{ }^{-2}\right)$ concentration (by precipitation with barium chloride crystals) and phosphate $\left(\mathrm{PO}_{4}^{-3}\right)$ concentration (using ascorbic acid method) in water samples,

- Laser fluorimeter manufactured by Quantalase Enterprises Pvt. Ltd., Indore, was used for the analysis of uranium in drinking water samples.

\section{RESULTS AND DISCUSSION}

All the collected samples were found to be colourless, odourless and tasteless. Turbidity of all the samples was recorded $<5$ NTU. The statistical analysis of water samples is shown in Table 2. The water samples were found to be slightly acidic to slightly alkaline; $\mathrm{pH}$ ranging from 6.7 to 7.82 in pre-monsoon $(\mathrm{PRM})$ and 6.74 - 7.77 in post-monsoon (POM) season. Total dissolved solids were 140 - $495 \mathrm{mg} / \mathrm{L}$ pre-monsoon and 132.5 - 500 $\mathrm{mg} / \mathrm{L}$ post-monsoon. Oxidation-reduction potential (ORP) was found to be $40-180 \mathrm{mV}$ in the pre-monsoon and $42-176 \mathrm{mV}$ in the post-monsoon season. ORP is a measure of oxidizing or reducing capacity of water, i.e., its ability to donate or receive electrons. Redox potential is a very important chemical parameter, as it characterizes the chemical state of an element in water. Although WHO has not prescribed any limit for ORP, any water sample having ORP below $-500 \mathrm{mV}$ is considered too strong to drink, hence not recommended for drinking purpose. Fluoride, chloride, nitrate and sulphate were found to be within the prescribed limit of Bureau of Indian Standards (BIS). Maximum value of fluoride was recorded at $0.26 \mathrm{mg} / \mathrm{L}$ in both seasons. Chloride was reported at $106.35 \mathrm{mg} / \mathrm{L}$ in PRM and $184.34 \mathrm{mg} / \mathrm{L}$ in POM. Nitrate was 42 $\mathrm{mg} / \mathrm{L}$ and $39.1 \mathrm{mg} / \mathrm{L}$ in PRM and POM respectively. Maximum value of hardness was $208 \mathrm{mg} / \mathrm{L}$ in both PRM and POM. The uranium concentration was also within the limit of $30 \mu \mathrm{g} / \mathrm{L}$, as prescribed by the WHO. The highest concentration of uranium in water samples was found to be $9.99 \mu \mathrm{g} / \mathrm{L}$ and 9.01 $\mu \mathrm{g} / \mathrm{L}$ in PRM and POM respectively. Total hardness $(\mathrm{TH})$, calcium $(\mathrm{Ca})$ and magnesium (Mg) concentrations were also found to be within the BIS limit (Table 2).

\section{Correlation analysis}

Statistical correlations between different parameters are represented in Table 3 and Table 4. TDS has shown good positive correlation with EC (1), salinity (0.96), chloride $(0.92)$, nitrate $(0.89)$, sulphate $(0.98)$, phosphate (0.91) and calcium (0.95). TDS is negatively correlated with $\mathrm{pH}$ and DO [10, 11]. Chloride has also shown positive linear relationship with nitrate $(0.97)$, sulphate (0.86), phosphate $(0.87)$, and calcium $(0.81)$, and negative correlation with total alkalinity ($0.873)$. Nitrate is in good correlation with sulphate (0.85), phosphate (0.92) and calcium (0.81). Sulphate has shown positive correlation with phosphate (0.94) and calcium (0.94). Phosphate is also in positive correlation with calcium (0.84) and in negative correlation with total alkalinity (- 0.809). Total hardness has shown a positive correlation of 0.90 and 0.92 with calcium and magnesium respectively (Table 3). Almost the same trend has been observed for the post-monsoon season (Table 4).

\section{Water Quality Index (WQI)}

Water quality index (WQI) is an important parameter used to determine the sustainability of water for drinking purposes [12]. It is calculated by using the standards prescribed by Bureau of Indian Standards and World Health Organization [13, 14]. To determining the WQI, firstly, all the parameters were assigned weight (wi) according to their importance in overall water quality for drinking purpose (Table 5). The maximum weight of 5 was assigned to TDS, fluoride, chloride, nitrate and sulphate, as they are highly important in assessing drinking water quality. 
Table 2. Statistics of physicochemical parameters

\begin{tabular}{|c|c|c|c|c|c|c|c|}
\hline \multirow[b]{2}{*}{ Parameters } & \multicolumn{3}{|c|}{ Pre-monsoon } & \multicolumn{3}{|c|}{ Post-monsoon } & \multirow{2}{*}{$\begin{array}{l}\text { Standard } \\
\text { limits }\end{array}$} \\
\hline & Minimum & Maximum & St. dev. & Minimum & Maximum & St. dev. & \\
\hline $\mathrm{pH}$ & 6.70 & 7.82 & 0.46 & 6.74 & 7.77 & 0.40 & $6.5-8.5$ \\
\hline TDS (mg/L) & 140 & 495 & 128.38 & 132.5 & 500 & 132.51 & 500 \\
\hline $\mathrm{EC}(\mu \mathrm{S} / \mathrm{cm})$ & 220 & 752 & 193.41 & 214 & 747 & 192.90 & - \\
\hline ORP (mv) & 40 & 180 & 53.52 & 42 & 176 & 50.74 & - \\
\hline Temperature $\left({ }^{\circ} \mathrm{C}\right)$ & 9.3 & 17.2 & 3.02 & 8.5 & 16.7 & 2.98 & \\
\hline Salinity (mg/L) & 100 & 400 & 116.62 & 100 & 400 & 116.62 & \\
\hline $\mathrm{DO}(\mathrm{mg} / \mathrm{L})$ & 5 & 8.10 & 1.32 & 4.8 & 11.2 & 2.31 & 5 \\
\hline Fluoride $(\mathrm{mg} / \mathrm{L})$ & 0.13 & 0.26 & 0.04 & 0.12 & 0.26 & 0.06 & $0.5-1.5$ \\
\hline Chloride (mg/L) & 49.63 & 106.35 & 23.98 & 42.54 & 184.34 & 52.02 & $250-1000$ \\
\hline Nitrate (mg/L) & $<0.1$ & 42 & 16.49 & $<0.1$ & 39.1 & 15.73 & 45 \\
\hline Sulphate $(\mathrm{mg} / \mathrm{L})$ & 5 & 22 & 6.67 & 4 & 20 & 7.25 & $200-400$ \\
\hline Phosphate (mg/L) & 0.13 & 2.5 & 0.03 & 0.11 & 2.5 & 0.04 & - \\
\hline Uranium $(\mu \mathrm{g} / \mathrm{L})$ & 0.18 & 10 & 3.81 & 0.09 & 9.01 & 3.45 & 30 \\
\hline $\begin{array}{c}\text { Total hardness }(\mathrm{TH}) \\
(\mathrm{mg} / \mathrm{L})\end{array}$ & 104 & 208 & 35.63 & 104 & 208 & 35.63 & $200-600$ \\
\hline Calcium (mg/L) & 17.96 & 37.19 & 6.45 & 16.67 & 37.19 & 6.95 & $75-200$ \\
\hline Magnesium (mg/L) & 14.37 & 27.19 & 17.59 & 15.15 & 34.98 & 6.31 & $30-100$ \\
\hline $\begin{array}{c}\text { Total alkalinity (TA) } \\
(\mathrm{mg} / \mathrm{L})\end{array}$ & 112 & 152 & 13.76 & 120 & 152 & 11.76 & $200-600$ \\
\hline Carbonate (mg/L) & 0 & 0 & 0 & 0 & 0 & 0 & \\
\hline $\begin{array}{c}\text { Bicarbonate } \\
\left(\mathrm{HCO}_{3}^{-}\right)(\mathrm{mg} / \mathrm{L}) \\
\end{array}$ & 112 & 152 & 11.76 & 120 & 152 & 11.76 & \\
\hline
\end{tabular}

Table 3. Table for correlation in the pre-monsoon season

\begin{tabular}{|c|c|c|c|c|c|c|c|c|c|c|c|c|c|c|c|c|c|}
\hline & $\mathrm{pH}$ & TDS & EC & $\mathrm{T}$ & Salinity & DO & $\mathrm{F}^{-}$ & $\mathrm{Cl}^{-}$ & $\mathrm{NO}_{3}{ }^{-}$ & $\mathrm{SO}_{4}{ }^{2-}$ & $\mathrm{PO}_{4}{ }^{3-}$ & $\mathrm{U}$ & $\mathrm{TH}$ & $\mathrm{Ca}$ & $\mathrm{Mg}$ & TA & $\mathrm{HCO}_{3}$ \\
\hline $\mathrm{pH}$ & 1 & & & & & & & & & & & & & & & & \\
\hline TDS & 0.22 & 1 & & & & & & & & & & & & & & & \\
\hline EC & 0.20 & 1.00 & 1 & & & & & & & & & & & & & & \\
\hline ORP & 0.32 & 0.64 & 0.63 & & & & & & & & & & & & & & \\
\hline $\mathrm{T}$ & $0 . \overline{0} 1$ & 0.63 & 0.60 & 1 & & & & & & & & & & & & & \\
\hline Salinity & $\begin{array}{c}- \\
0.06 \\
\end{array}$ & 0.96 & 0.97 & 0.42 & 1 & & & & & & & & & & & & \\
\hline DO & 0.01 & 0.17 & 0.19 & 0.22 & -0.26 & 1 & & & & & & & & & & & \\
\hline $\mathrm{F}^{-}$ & $0 . \overline{48}$ & 0.40 & 0.36 & 0.67 & 0.13 & 0.13 & 1 & & & & & & & & & & \\
\hline $\mathrm{Cl}^{-}$ & 0.06 & 0.92 & 0.94 & 0.35 & 0.98 & $0 . \overline{13}$ & 0.03 & 1 & & & & & & & & & \\
\hline $\mathrm{NO}_{3}^{-}$ & 0.07 & 0.89 & 0.90 & 0.41 & 0.92 & 0.12 & 0.04 & 0.97 & 1 & & & & & & & & \\
\hline $\mathrm{SO}_{4}{ }^{2-}$ & $\begin{array}{c}- \\
0.19 \\
\end{array}$ & 0.98 & 0.97 & 0.64 & 0.89 & $\begin{array}{c}- \\
0.14 \\
\end{array}$ & 0.53 & 0.86 & 0.85 & 1 & & & & & & & \\
\hline $\mathrm{PO}_{4}{ }^{3-}$ & 0.07 & 0.91 & 0.90 & 0.50 & 0.84 & 0.08 & 0.38 & 0.87 & 0.92 & 0.94 & 1 & & & & & & \\
\hline $\mathrm{U}$ & 0.56 & 0.21 & 0.22 & $\begin{array}{c}- \\
0.21 \\
\end{array}$ & 0.35 & 0.52 & -0.59 & 0.51 & 0.63 & 0.16 & 0.43 & 1 & & & & & \\
\hline TH & 0.68 & 0.74 & 0.72 & 0.93 & 0.61 & 0.30 & 0.39 & 0.58 & 0.65 & 0.70 & 0.61 & 0.11 & 1 & & & & \\
\hline $\mathrm{Ca}$ & 0.47 & 0.95 & 0.94 & 0.83 & 0.85 & 0.00 & 0.50 & 0.80 & 0.81 & 0.94 & 0.84 & 0.11 & 0.90 & 1 & & & \\
\hline $\mathrm{Mg}$ & $0 . \overline{75}$ & 0.41 & 0.39 & 0.85 & 0.29 & 0.53 & 0.22 & 0.28 & 0.39 & 0.36 & 0.29 & 0.10 & 0.92 & 0.65 & 1 & & \\
\hline TA & 0.48 & 0.67 & $\begin{array}{c}- \\
0.69 \\
\end{array}$ & $\begin{array}{c}- \\
0.01 \\
\end{array}$ & -0.78 & 0.11 & 0.22 & -0.87 & -0.91 & -0.64 & -0.81 & $\begin{array}{c}- \\
0.82 \\
\end{array}$ & $\begin{array}{c}- \\
0.29\end{array}$ & 0.50 & $0 . \overline{0}$ & 1 & \\
\hline $\mathrm{HCO}_{3}^{-}$ & $0 . \overline{73}$ & 0.34 & $0 . \overline{38}$ & 0.51 & -0.56 & 0.37 & 0.47 & -0.62 & -0.53 & -0.28 & -0.40 & 0.59 & 0.26 & 0.05 & 0.50 & 0.78 & 1 \\
\hline
\end{tabular}


Table 4. Table for correlation in the post-monsoon season

\begin{tabular}{|c|c|c|c|c|c|c|c|c|c|c|c|c|c|c|c|c|c|c|}
\hline & $\mathrm{pH}$ & TDS & EC & ORP & $\mathrm{T}$ & Salinity & DO & $\mathrm{F}$ & $\mathrm{Cl}^{-}$ & $\mathrm{NO}_{3}{ }^{\circ}$ & $\mathrm{SO}_{4}^{2-}$ & $\mathrm{PO}_{4}{ }^{3-}$ & $\mathrm{U}$ & TH & $\mathrm{Ca}$ & $\mathrm{Mg}$ & TA & $\mathrm{HCO}_{3}$ \\
\hline $\mathrm{pH}$ & 1 & & & & & & & & & & & & & & & & & \\
\hline TDS & 0.37 & 1 & & & & & & & & & & & & & & & & \\
\hline $\mathrm{EC}$ & 0.36 & 1.00 & 1 & & & & & & & & & & & & & & & \\
\hline ORP & $0 . \overline{27}$ & $0 . \overline{6}$ & 0.66 & 1 & & & & & & & & & & & & & & \\
\hline $\mathrm{T}$ & 0.85 & 0.62 & 0.61 & 0.23 & 1 & & & & & & & & & & & & & \\
\hline Salinity & 0.21 & 0.96 & 0.97 & $\begin{array}{c}-\overline{6} \\
0.64\end{array}$ & 0.45 & 1 & & & & & & & & & & & & \\
\hline DO & 0.46 & 0.00 & 0.01 & 0.66 & 0.01 & 0.00 & 1 & & & & & & & & & & & \\
\hline $\mathrm{F}^{-}$ & 0.79 & 0.58 & 0.57 & $\begin{array}{c}- \\
0.09\end{array}$ & 0.73 & 0.37 & 0.44 & 1 & & & & & & & & & & \\
\hline $\mathrm{Cl}-$ & $\begin{array}{c}- \\
0.44 \\
\end{array}$ & 0.93 & 0.94 & $\begin{array}{c}- \\
0.40 \\
\end{array}$ & 0.54 & 0.95 & 0.28 & 0.54 & 1 & & & & & & & & & \\
\hline $\mathrm{NO}_{3}{ }^{-}$ & $\begin{array}{c}- \\
0.03 \\
\end{array}$ & 0.91 & 0.91 & $\begin{array}{r}- \\
0.85 \\
\end{array}$ & 0.43 & 0.94 & 0.35 & 0.21 & 0.79 & 1 & & & & & & & & \\
\hline $\mathrm{SO}_{4}{ }^{2-}$ & 0.19 & 0.93 & 0.93 & 0.82 & 0.51 & 0.86 & 0.16 & 0.57 & 0.77 & 0.88 & 1 & & & & & & & \\
\hline $\mathrm{PO}_{4}^{3--}$ & 0.07 & 0.90 & 0.90 & 0.89 & 0.44 & 0.84 & 0.27 & 0.47 & 0.71 & 0.90 & 0.99 & 1 & & & & & & \\
\hline $\mathrm{U}$ & 0.66 & 0.22 & 0.22 & 0.76 & -0.20 & 0.35 & 0.84 & 0.57 & 0.04 & 0.61 & 0.31 & 0.43 & 1 & & & & & \\
\hline $\mathrm{TH}$ & $\begin{array}{c}- \\
0.65 \\
\end{array}$ & 0.81 & 0.80 & 0.54 & 0.94 & 0.68 & 0.20 & 0.65 & 0.67 & 0.71 & 0.75 & 0.70 & 0.11 & 1 & & & & \\
\hline $\mathrm{Ca}$ & $\begin{array}{r}0.24 \\
\end{array}$ & 0.37 & 0.35 & $\begin{array}{c}- \\
0.64 \\
\end{array}$ & 0.65 & 0.18 & 0.66 & 0.37 & 0.05 & 0.41 & 0.53 & 0.55 & 0.31 & 0.73 & 1 & & & \\
\hline $\mathrm{Mg}$ & 0.72 & 0.87 & 0.87 & 0.31 & 0.85 & 0.81 & 0.16 & 0.64 & 0.89 & 0.69 & 0.67 & 0.60 & 0.06 & 0.89 & 0.33 & 1 & & \\
\hline $\mathrm{TA}$ & 0.61 & 0.35 & 0.37 & 0.43 & 0.48 & -0.56 & 0.05 & 0.38 & 0.42 & -0.54 & -0.34 & -0.40 & 0.58 & 0.20 & 0.41 & 0.0 & 1 & \\
\hline $\mathrm{HCO}_{3}{ }^{-}$ & 0.61 & 0.35 & 0.37 & 0.43 & 0.48 & -0.56 & 0.05 & 0.38 & 0.42 & -0.54 & -0.34 & -0.40 & 0.58 & 0.20 & 0.41 & 0.0 & 1 & 1 \\
\hline
\end{tabular}

Table 5. Relative weight of chemical parameters

\begin{tabular}{|c|c|c|c|}
\hline Parameters & $\begin{array}{l}\text { Indian } \\
\text { Standard } \\
\text { (BIS) }\end{array}$ & $\begin{array}{c}\text { Weight } \\
\left(w_{\mathrm{i}}\right)\end{array}$ & $\begin{array}{c}\text { Relative } \\
\text { weight } \\
\left(W_{\mathrm{i}}\right)\end{array}$ \\
\hline $\mathrm{pH}$ & 8.5 & 4 & 0.103 \\
\hline TDS (mg/L) & 500 & 5 & 0.128 \\
\hline Fluoride (mg/L) & 1 & 5 & 0.128 \\
\hline Chloride (mg/L) & 250 & 5 & 0.128 \\
\hline Nitrate $(\mathrm{mg} / \mathrm{L})$ & 45 & 5 & 0.128 \\
\hline Sulphate (mg/L) & 200 & 5 & 0.128 \\
\hline $\begin{array}{l}\text { Total hardness } \\
(\mathrm{mg} / \mathrm{L})\end{array}$ & 200 & 2 & 0.051 \\
\hline Calcium (mg/L) & 75 & 3 & 0.077 \\
\hline \multirow[t]{2}{*}{$\begin{array}{c}\text { Magnesium } \\
(\mathrm{mg} / \mathrm{L})\end{array}$} & 30 & 3 & 0.077 \\
\hline & & $\Sigma \mathrm{W}_{\mathrm{i}}=37$ & $\Sigma \mathrm{W}_{\mathrm{i}}=0.996$ \\
\hline
\end{tabular}

A minimum weight of 1 was assigned to phosphate and bicarbonate. All other parameters, like $\mathrm{pH}$, total hardness, calcium and magnesium were assigned a weight between 1 and 5 depending on their importance in the water quality assessment [15]. In the next step, relative weight was calculated with the help of weight (rank), using the following equation:

$$
W_{\mathrm{i}}=\frac{w_{\mathrm{i}}}{\sum_{\mathrm{i}=1}^{\mathrm{n}} w_{\mathrm{i}}}
$$

where: $W_{\mathrm{i}}$ is relative weight, $w_{\mathrm{i}}$ is weight of each parameter (rank) and $n$ is number of parameters.

The calculated relative weight is given in Table 5. In the next stage, quality assessment $\left(q_{\mathrm{i}}\right)$ is done by dividing the measured concentration of the parameter with its standard value:

$$
q_{\mathrm{i}}=\frac{C_{\mathrm{i}}}{S_{\mathrm{i}}} \times 100
$$

where: $q_{\mathrm{i}}$ is quality rating, $C_{\mathrm{i}}$ is measured concentration of parameter $(\mathrm{mg} / \mathrm{L})$ and $S_{\mathrm{i}}$ is concentration of the parameter $(\mathrm{mg} / \mathrm{L})$ given by BIS.

In the final step, $S I$ is calculated for individual parameter by using the following equation:

$$
S I_{\mathrm{i}}=W_{\mathrm{i}} \cdot q_{\mathrm{i}}
$$

where: $S I_{\mathrm{i}}$ is sub index of the $\mathrm{i}^{\text {th }}$ parameter. 
The WQI range and the corresponding water quality are given in Table 6 , on the basis of which it can be easily analysed whether the water is fit for consumption or not.

Table 6. WQI range and corresponding water quality

\begin{tabular}{|c|c|}
\hline WQI & Quality of water \\
\hline$<50$ & Excellent \\
\hline $50-100.1$ & Good \\
\hline $100-200.1$ & Poor \\
\hline $200-300.1$ & Very poor \\
\hline$>300$ & $\begin{array}{c}\text { Not suitable for drinking } \\
\text { purpose }\end{array}$ \\
\hline
\end{tabular}

From the study of WQI it was found that the water quality in both the seasons was comparable. Samples no. 2, 3 and 4 having excellent quality of water in PRM and POM are followed by two samples (1 and 5) having good quality of water in both seasons (Table 7).

Table 7. Calculation of WQI for individual samples

\begin{tabular}{|c|c|c|c|c|}
\hline $\begin{array}{c}\text { Sample } \\
\text { No. }\end{array}$ & PRM & $\begin{array}{c}\text { Quality of } \\
\text { water }\end{array}$ & POM & $\begin{array}{c}\text { Quality of } \\
\text { water }\end{array}$ \\
\hline 1 & 53.83 & Good & 53.31 & Good \\
\hline 2 & 49.25 & Excellent & 48.88 & Excellent \\
\hline 3 & 27.07 & Excellent & 26.38 & Excellent \\
\hline 4 & 35.05 & Excellent & 34.62 & Excellent \\
\hline 5 & 63.53 & Good & 65.48 & Good \\
\hline
\end{tabular}

\section{Box plot}

Box plots were used to visually summarize and compare groups of data. In the box plot given below, some important ions are represented (Figure 2 and Figure 3). The upper and lower quartiles of data represent top and bottom of the rectangle. The line inside the rectangular box represents the median value of the data [16]. From both figures it is quite clear that there is not so much difference in the concentration of most of the ions in water samples. Figure 2 shows that there are two outliers in Mg in PRM (Sample no. 3 and 5) and Figure 3 shows sample no. 4 and 5 as outliers.

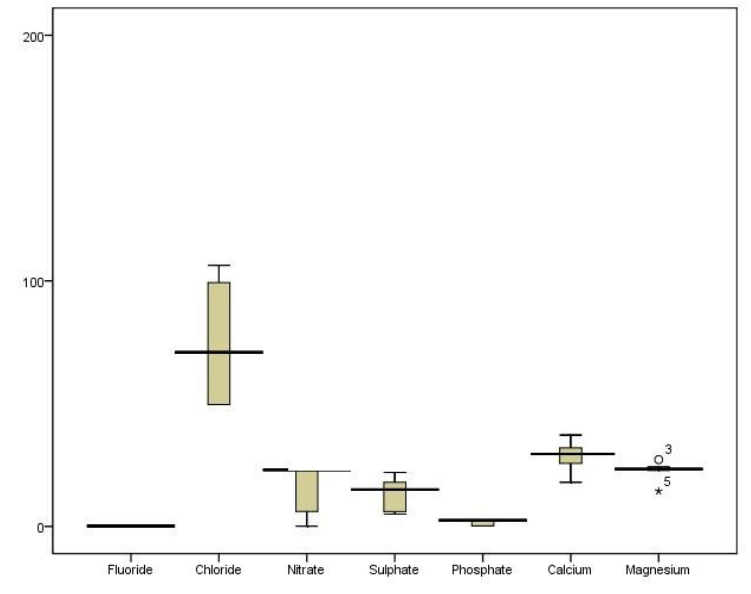

Figure 2. Box plot for pre-monsoon

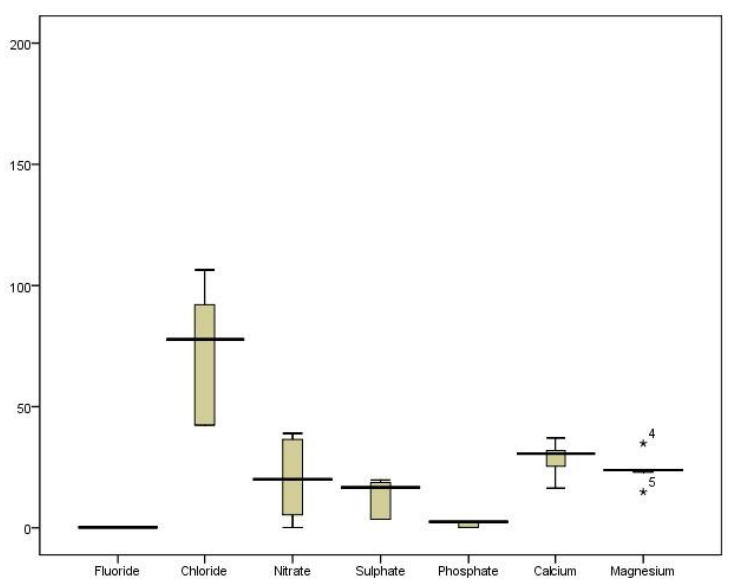

Figure 3. Box plot for post-monsoon

\section{CONCLUSION}

The physicochemical study reveals that total dissolved solids of only one sample are approaching the limit of $500 \mathrm{mg} / \mathrm{L}$, which is the permissible limit for TDS in drinking water according to BIS. All the parameters are found to be well within the prescribed limit. Water quality index (WQI) also shows that the quality of water is good to excellent and can be used for drinking purposes. The correlation table shows a good linear relationship between TDS and EC, TDS and chloride, TDS and sulphate and phosphate. Overall, it was found that all the selected samples are suitable for drinking purposes. If all these historic aesthetics are maintained properly with regular monitoring, they can be used as an alternative by the people in their surrounding for various purposes. 


\section{REFERENCES}

[1] A.N. Parikh, P.C. Mankodi, Limnology of Sama Pond, Vadodara City, Gujarat, Research Journal of Recent Sciences 1(2012) 1, 16-21.

[2] S. Mumtazuddin, A. Azad, B. Prabhat, R. Rakesh, Physico-chemical analysis of groundwater of the Budhi Gandak belt in Muzaffarpur district, India, International Research Journal of Environment Sciences 1(2012) 1, 7-11.

[3] S. Parihar, A. Kumar, A. Kumar, R. Gupta, M. Pathak, A. Shrivastav, A. Pandey, Physico-Chemical and Microbiological Analysis of Underground Water in and Around Gwalior City, MP, India, Research Journal of Recent Sciences 1(2012) 6, 62-65.

[4] G. Simiyu, J. Ngetich, T. Esipila, Assessment of spring water quality and quantity, and health implications in Tongaren division, Nzoia River catchment, Kenya, African Journal of Ecology 47(2009) 1, 99-104. https://doi.org/10.1111/j.13652028.2008.01055.x

[5] C. Shivayogimath, P. Kalburgi, U. Deshannavar, D. Virupakshaiah, Water Quality Evaluation of River Ghataprabha, India, International Research Journal of Environment Sciences 1(2012) 1, 12-18.

[6] B.S. Bajwa, S, Kumar, S. Singh, S.K. Sahoo, R.M. Tripathi, Uranium and other heavy toxic elements distribution in the drinking water samples of SWPunjab, India, Journal of Radiation Research and Applied Sciences 10(2017) 1 ,

https://doi.org/10.1016/j.jrras.2015.01.00 $\underline{2}$

[7] ICRP, The Recommendations of the International Commission on Radiological Protection, Annals on the ICRP, 2007.

[8] ATSDR, Toxicological Profile for Uranium, U.S. Department of Health and Human Services, Public Health Service, Atlanta, Georgia, 2013.
[9] AERB, Drinking water specifications in India. Department of Atomic Energy, Govt. of India, 2004.

[10] U. Mohan, R. Singh, P. Singh, Water Quality Assessment and Physicochemical Parameters of Groundwater in District Hapur, Uttar Pradesh, India, Environment Conservation Journal 14(2013) 3, 143149.

https://doi.org/10.36953/ECJ.2013.1432 $\underline{4}$

[11] B. Selakoti, S. Rao, A study on seasonal fluctuations in physico-chemical variables in spring fed Kosi River at Almora province from central Himalaya, India, International journal of Current microbiology biology and applied sciences 4(2015) 4, 418-425.

[12] M. Vasanthavigar, K. Srinivasamoorthy, K. Vijayaragavan, R. Ganthi, S. Chidambaram, P. Anandhan, R. Manivannan, S. Vasudevan, Application of water quality index for groundwater quality assessment: Thirumanimuttar sub-basin, Tamilnadu, India, Environmental Monitoring and Assessment 171(2010), 595-605. https://doi.org/10.1007/s10661-0091302-1

[13] BIS (Bureau of Indian Standards), Indian Standard drinking water-specification, $1^{\text {st }}$ rev., 1991, 1-8.

[14] WHO, Guidelines for drinking water quality, $2^{\text {nd }}$ ed., Recommendations, Geneva: World Health Organization, $1993,188$.

[15] K. Srinivasamoorthy, S. Chidambaram, M. Prasanna, M. Vasanthavihar, J. Peter, P. Anandhan, Identification of major sources controlling groundwater chemistry from a hard rock terrain - A case study from Mettur taluk, Salem district, TamilNadu, India, Journal of Earth System Science 117(2008) 1, 4958.

[16] A. Tizro, K. Voudouris, Groundwater quality in the semi-arid region of the Chahardouly basin, West Iran, Hydrological Processes 22(2008) 16, 3066-3078. https://doi.org/10.1002/hyp.6893 